\title{
Comparison between retinal nerve fiber layer and macular thickness measured with OCT detecting progressive axonal loss following traumatic optic neuropathy
}

Comparação entre as medidas da espessura da camada de fibras nervosas da retina e da mácula pela tomografia de coerência óptica na detecção da perda axonal progressiva decorrente à neuropatia óptica traumática

\author{
Leonardo Provetti Cunha ${ }^{1}$ \\ Luciana Virginia Ferreira Costa-Cunha ${ }^{2}$ \\ Roberto Freire Santiago Malta ${ }^{3}$ \\ Mário Luiz Ribeiro Monteiro ${ }^{4}$
}

From the Division of Ophthalmology, University of São Paulo Medical School, São Paulo, Brazil.

Pós-graduando (Doutorado) da divisão de Clínica Oftalmológica do Hospital das Clínicas da Faculdade de Medicina da Universidade de São Paulo - USP - São Paulo (SP) - Brazil

${ }^{2}$ Pós-graduanda (Doutorado) da divisão de Clínica Oftalmológica do Hospital das Clínicas da Faculdade de Medicina da USP - São Paulo (SP) - Brazil.

${ }^{3}$ Professor Livre Docente da Clínica Oftalmológica do Hospital das Clínicas da USP - São Paulo (SP) - Brazil.

${ }^{4}$ Livre-docente, Professor Adjunto da divisão de Clínica Oftalmológica da Faculdade de Medicina da USP São Paulo (SP) - Brazil

Address for correspondence: Leonardo Provetti $\mathrm{Cu}$ nha. Av. Barão do Rio Branco, 4.051 - Juiz de Fora (MG) CEP 36021-630

E-mail: leonardo_provetti@yahoo.com.br

Recebido para publicação em 28.10.2008

Última versão recebida em 03.08.2009

Aprovação em 04.08.2009

\begin{tabular}{l} 
ABSTRACT \\
\hline Purpose: To compare the optical coherence tomography retinal nerve \\
fiber layer and macular thickness measurements for detection of pro- \\
gressive axonal loss following acute traumatic optic neuropathy in a \\
longitudinal study. Methods: Three patients with unilateral traumatic \\
optic neuropathy were evaluated sequentially after trauma. Macular and \\
retinal nerve fiber layer thickness measurements were obtained using \\
optical coherence tomography weekly for five weeks and around the \\
twelfth week after trauma. Results: All patients showed progressive \\
macular and retinal nerve fiber layer thickness reduction. The mean \\
retinal nerve fiber layer thickness on the first week was $114 \mu$ m and \\
reduced sequentially over the first five weeks and was $46 \mu$ m on the \\
twelfth week. For macular parameters, the mean average thickness on the \\
first week was $248 \mu$ and also reduced over the first five weeks and was \\
$218 \mu$ m on the twelfth week. When compared to the initial measurement, \\
macular thickness average reduction rate at the $12^{\text {th }}$ week was $14 \%$ while \\
peripapillary retinal nerve fiber layer thickness average reduction rate \\
was $59 \%$. Conclusions: Although both measurements reduce signifi- \\
cantly after trauma, retinal nerve fiber layer thickness measurements \\
show greater and faster retinal neural reduction if compared to macular \\
thickness measurements in traumatic optic neuropathy. \\
\hline
\end{tabular}

Keywords: Optic nerve injuries; Tomography, optical coherence; Retina; Retinal ganglion cells; Nerve fibers; Macula; Visual acuity

\section{INTRODUCTION}

Optical coherence tomography (OCT) is a non-invasive optical imaging technique that provides high-resolution, cross-sectional, imaging of the human retina from which estimates of retinal layers thickness can be made $^{(1)}$. Previous studies have documented that both retinal nerve fiber layer (RNFL) and macular thickness measurements were able to demonstrate axonal loss in patients with glaucoma as well as in other optic pathway conditions including band atrophy of the optic nerve ${ }^{(2)}$. Most studies have addressed the use of RNFL thickness measurements for quantifying neural loss but macular thickness measurements can also be 
used for such purpose particularly in eyes with optic disc anomalies or edema. Although several studies have investigated the changes in RNFL and macular thickness measurements in optic pathway diseases, no study has investigated longitudinally which set of measurements is altered first in the course of optic nerve diseases.

Although previous studies have documented in single case-reports that OCT is able to document both $\mathrm{RNFL}^{(3)}$ and macular thickness ${ }^{(4)}$ measurements in traumatic optic neuropathy (TON), no study has performed a direct comparison between RNFL and macular thickness measurements in such patients. The purpose of this study was to evaluate longitudinally the RNFL and macular thickness measurements following TON in three patients using OCT and to compare RNFL and macular thickness measurements documenting progressive retinal axonal loss.

\section{METHODS}

Three eyes of three patients with TON were examined sequentially for three months after trauma. All patients had a history of acute indirect traumatic optic nerve injury, without any trauma to the eye (Table 1).

Systemic, neurological and neuro-imaging findings were unremarkable in all patients. Patient characteristics and visual outcomes are summarized in Table 1. All patients showed acute and severe visual loss with relative afferent pupillary defect on the affected eye, a normal looking fundus examination at the first examination, and developed severe optic disc pallor on follow-up. All patients were treated with intravenous methylprednisolone (1 gram/day for 3 days) followed by oral prednisone tapering in five weeks.

Patients underwent ocular imaging with dilated pupils using a commercially available Stratus-OCT (Carl Zeiss Meditec, Dublin, California, USA). Peripapillary RNFL and macular thickness scans were obtained weekly from the first to the fifth week after trauma. Measurements were also obtained at the twelfth week after the optic nerve injury. Quality assessment of Stratus OCT scans was evaluated by an experienced examiner. Good-quality scans had to have focused images and signal strength equal to or higher than 7 , and presence of a centered ring around the optic disc for RNFL scans. For macula scans, the radial scans had to be centered on the fovea. External fixation was used since all patients presented severe visual loss in the study eye. Approval from the Institutional Review Board Ethics Committee was obtained for the study.
The study followed the principles of the Declaration of Helsinki and informed consent was obtained from all participants.

The fast RNFL algorithm was used to obtain RNFL thickness measurements with Stratus-OCT. Three images were acquired from each subject, with each image consisting of 256 A-scans along a $3.4 \mathrm{~mm}$-diameter circular ring around the optic disc. Peripapillary $\left(360^{\circ}\right.$ measure) RNFL thickness average was automatically calculated by existing Stratus-OCT software (version 4.0.1). The fast macular thickness protocol was used to obtain macular thickness measurements. Average macular thickness was calculated as the weighted average of the sectoral macular thickness measurements excluding the fovea. In order to improve the reproducibility, for each session at least three scans protocols for both RNFL and macular measurements in each patient were performed.

\section{RESULTS}

Three patients showed progressive reduction of both macular and peripapillary RNFL average thickness measurements after TON documented sequentially by OCT (Figures 1 and 2). Table 2 shows macular and RNFL thickness measurements along the first five weeks after trauma with remarkable reduction in the twelfth week. Based on the values from a large series of normal individuals recently examined with the same equipment (Stratus-OCT) at our institution ${ }^{(5)}$ and using 2 standard deviation as the lower limit of normal, values below $223 \mu \mathrm{m}$ and $88 \mu \mathrm{m}$ were considered as the lower limit of normal for macular and RNFL thickness measurements, respectively. When these values were used, average RNFL thickness reduction became more apparent 4 weeks after trauma although some reduction was observed 2 weeks after trauma. Using the same reasoning, macular thickness reduction became apparent only at the $12^{\text {th }}$ week after trauma although some reduction could be seen at least at the $5^{\text {th }}$ week after trauma (Table 2).

When compared to the values obtained at the first measurement after trauma, macular thickness at the $12^{\text {th }}$ week was reduced in $11 \%, 14 \%$ and $14 \%$ in cases one, two and three, respectively. Average macular reduction rate in the three patients was 14\% (Table 2, Figure 1). Accordingly, based on the values from the first measurement after trauma, RNFL thickness measure ment reduction rate at the $12^{\text {th }}$ week was $56 \%, 64 \%$ and $58 \%$ in cases one, two and three, respectively. Average RNFL thickness reduction rate in the three cases was 59\% (Table 2, Figure 2).

\begin{tabular}{|lcccccc|}
\hline & \multicolumn{5}{c|}{ Table 1. Characteristics and visual outcomes of three patients with traumatic optic neuropathy } \\
Case & Age & Gender & Eye & Initial VA & Type of injury \\
1 & 24 & Female & OD & LP & Stab injury to the orbit \\
2 & 20 & Male & OD & LP & Head trauma after fall \\
3 & 34 & Female & OS & HM & Head trauma after bicycle fall \\
VA= visual acuity; OD= right eye; OS= left eye; $L P=$ light perception; HM= hand motion & & HM \\
\hline
\end{tabular}




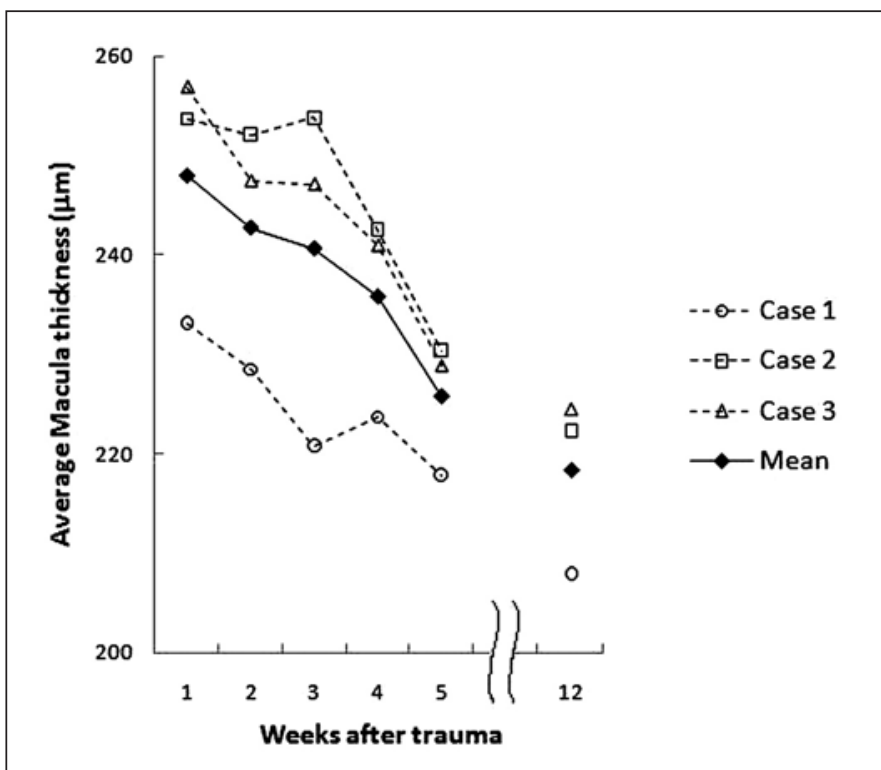

Figure 1 - Macular thickness measurements $(\mu \mathrm{m})$ over the first five weeks and in the twelfth week in three patients after acute traumatic optic neuropathy

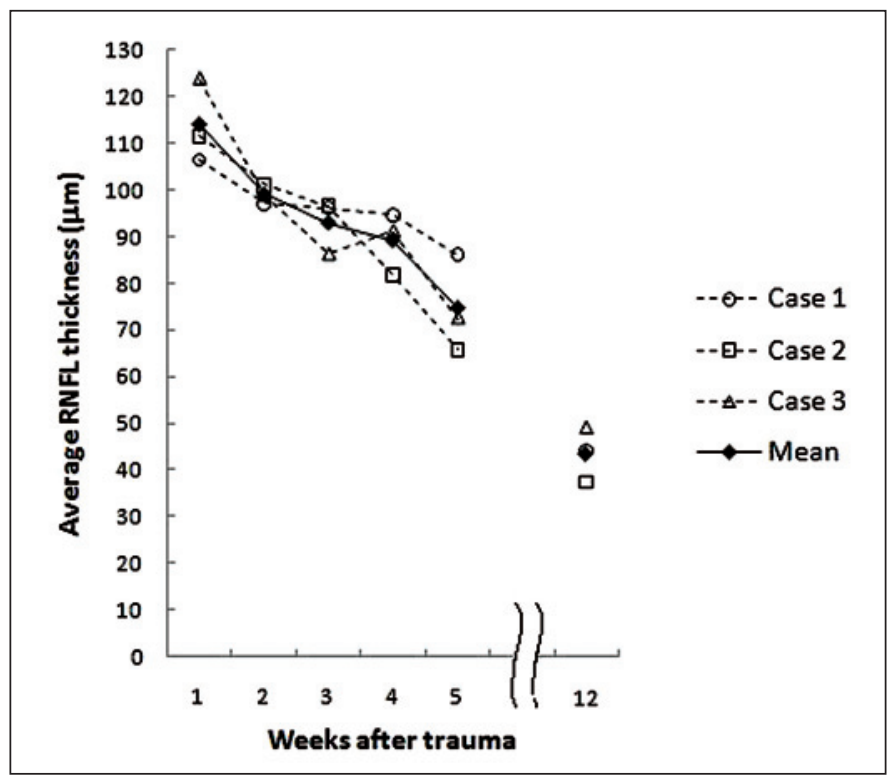

Figure 2 - Retinal nerve fiber layer thickness measurements $(\mu \mathrm{m})$ over the first five weeks and in the twelfth week in three patients after acute traumatic optic neuropathy

\section{DISCUSSION}

Most studies have employed RNFL thickness to evaluate axonal damage, mainly for glaucoma patients but also in other anterior pathway optic nerve diseases, such as demyelinating and compressive optic neuropathies ${ }^{(5)}$. More recently, several studies have shown that macular thickness measurements can also be used as indicator of neural damage ${ }^{(6-9)}$. As the ganglion cell layer accounts for up to $40 \%$ of the thickness in the macular area, estimation of macular thickness can be used to investigate possible ganglion cell loss ${ }^{(6,8)}$. Although RNFL measurements are usually considered the most reliable way to quantify axonal loss, the use of macular thickness measurements as an estimator of neural loss may be of interest in some cases, particularly if paripapillary RNFL thickness assessment is impaired in conditions such as optic disc edema, optic disc anomalies and in cases of large peripapillary scarring or atrophies. In fact, previous studies have shown that OCT macular thickness measurements are significantly thinner in many optic nerve diseases, like glaucoma ${ }^{(6,8)}$ and band atrophy of the optic nerve from chiasmal compression ${ }^{(2)}$ and could be a useful tool for clinical assessment of ganglion cell loss in many optic nerve diseases.

Of interest, RNFL thickness represent the measurement of all retinal nerve fibers entering the optic disc, while macular thickness represents the measurement of the retina in macular $\operatorname{area}^{(10)}$. Studies comparing macular and RNFL thickness measurements are important for understanding how they can be used for diagnosis and during follow-up in conditions with nerve phase loss, or optic nerve diseases. Furthermore, it might be possible that both sets of measurements can be used in association to increase diagnostic sensitivity and specificity.

Recently, four reports ${ }^{(11-14)}$ documented RNFL loss after TON using scanning laser polarimetry (SLP) and showed that RNFL thickness measurements first decreased 4 to 9 weeks after trauma. On the other hand some authors ${ }^{(3)}$, using OCT after TON, found that RNFL thickness measurements started to decrease 20 days after the trauma, suggesting that OCT can show RNFL loss earlier when compared SLP. Recently, a case of progressive macular thinning after severe indirect TON was documented using $\mathrm{OCT}^{(4)}$. Progressive reduction of macular thickness parameters was observed in conjunction with thinning of RNFL thickness. At time 77 days after trauma, severe thinning of the macular thickness parameters was observed.

In the present study, all three patients showed progressive macular and RNFL thickness reduction documented sequentially by OCT after trauma. RNFL thickness measurements showed greater reduction than macular thickness measurements. The reduction rate of RNFL thickness was greater than $55 \%$ in all cases, while for the macular thickness parameters, the reduction rate was approximately $13 \%$. Furthermore, RNFL thickness measurements reduced at least 2 weeks earlier than macular thickness measurement.

\section{CONCLUSION}

The current study indicates that both macular and RNFL thickness measurements may be used to assess and monitor axonal loss after acute optic nerve diseases such as traumatic optic neuropathy. Although both sets of measurements can be used to monitor retinal neural damage, clinicians should be aware that macular thickness measurements show a smaller and later reduction in size when compared to RNFL thickness measurements. 


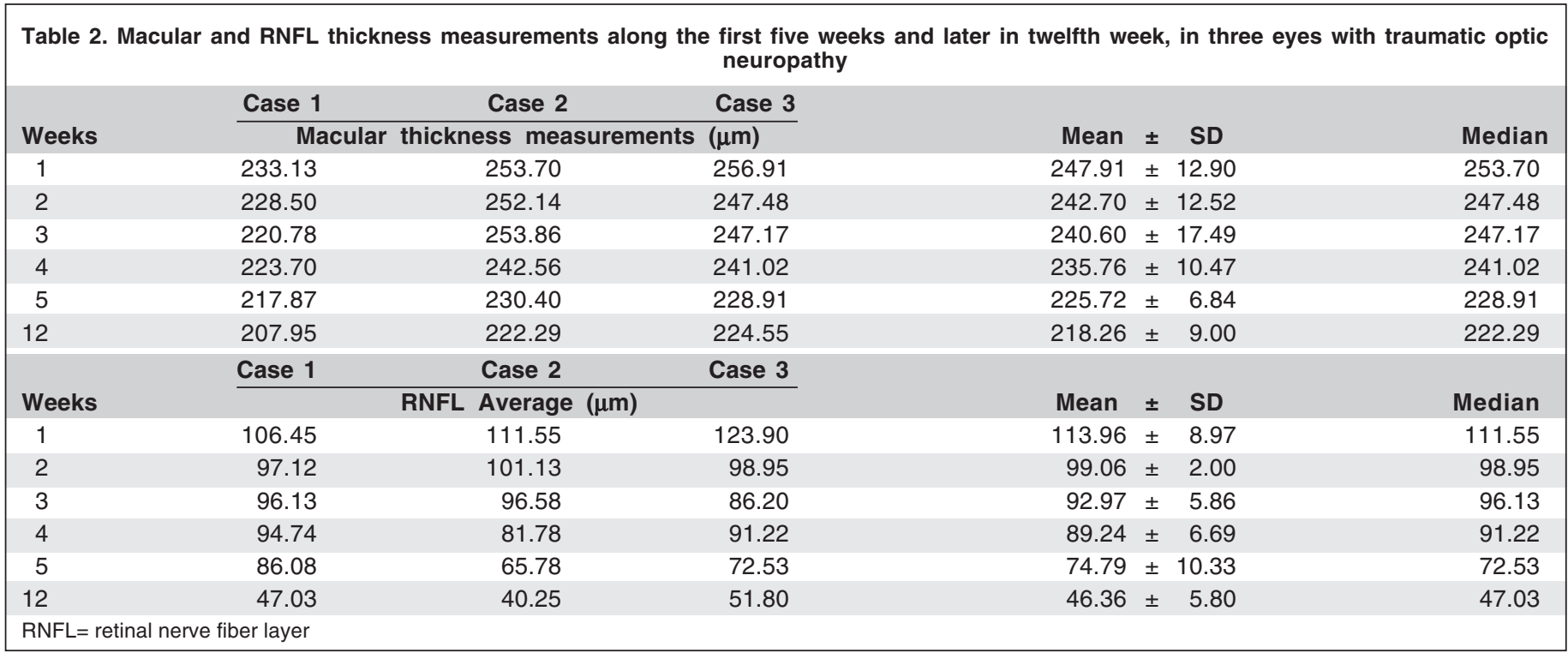

\section{RESUMO}

Objetivo: Comparar as medidas da espessura da camada de fibras nervosas da retina e macular obtidas pela tomografia de coerência óptica na detecção da perda axonal progressiva após neuropatia óptica traumática aguda e durante o seguimento clínico. Métodos: Três pacientes com neuropatia óptica traumática unilateral aguda foram avaliados sequencialmente após o trauma. Medidas da espessura macular e da camada de fibras nervosas da retina foram obtidas pela tomografia de coerência óptica semanalmente por 5 semanas consecutivas e ao redor da décima segunda semana após o trauma. Resultados: Todos os pacientes apresentaram redução progressiva dos valores da espessura macular e da camada de fibras nervosas da retina. A espessura média da camada de fibras nervosas da retina foi de $114 \mu \mathrm{m}$ na primeira semana e reduziu sequencialmente ao longo das primeiras cinco semanas e foi de $46 \mu \mathrm{m}$ na décima segunda semana. Para parâmetros macular, a espessura média foi de $248 \mu \mathrm{m}$ na primeira semana, e também reduziu ao longo das primeiras cinco semanas e foi de $218 \mu \mathrm{m}$ na décima segunda semana. Quando comparado às medidas iniciais, a taxa de redução das médias da espessura macular foi $14 \%$ na décima segunda semana após o trauma, enquanto que a taxa de redução das médias da espessura da camada de fibras nervosas da retina foi $59 \%$. Conclusões: Os valores da espessura da camada de fibras nervosas da retina apresentaram uma redução maior e mais rápida se comparada às medidas da espessura macular na neuropatia óptica traumática.

Descritores: Traumatismos do nervo óptico; Tomografia de coerência óptica; Retina; Fibras nervosas; Células ganglionares da retina; Mácula; Acuidade visual

\section{REFERENCES}

1. Huang D, Swanson EA, Lin CP, Schuman JS, Stinson WG, Chang W, et al. Optical coherence tomography. Science. 1991;254(5035):1178-81.

2. Moura FC, Medeiros FA, Monteiro ML. Evaluation of macular thickness measurements for detection of band atrophy of the optic nerve using optical coherence tomography. Ophthalmology. 2007;114(1):175-81.

3. Medeiros FA, Moura FC, Vessani RM, Susanna R Jr. Axonal loss after traumatic optic neuropathy documented by optical coherence tomography. Am J Ophthalmol. 2003;135(3):406-8.

4. Vessani RM, Cunha LP, Monteiro ML. Progressive macular thinning after indirect traumatic optic neuropathy documented by optical coherence tomography. Br J Ophthalmol. 2007;91(5):697-8.

5. Costa-Cunha LV, Cunha LP, Malta RF, Monteiro ML. Comparison of Fourierdomain and time-domain optical coherence tomography in the detection of band atrophy of the optic nerve. Am J Ophthalmol. 2009;147(1):56-63.

6. Greenfield DS, Bagga H, Knighton RW. Macular thickness changes in glaucomatous optic neuropathy detected using optical coherence tomography. Arch Ophthalmol. 2003;121(1):41-6.

7. Guedes V, Schuman JS, Hertzmark E, Wollstein G, Correnti A, Mancini R, et al. Optical coherence tomography measurement of macular and nerve fiber layer thickness in normal and glaucomatous human eyes. Ophthalmology. 2003; 110(1):177-89.

8. Lederer DE, Schuman JS, Hertzmark E, Heltzer J, Velasquez LJ, Fujimoto JG, et al. Analysis of macular volume in normal and glaucomatous eyes using optical coherence tomography. Am J Ophthalmol. 2003;135(6):838-43.

9. Medeiros FA, Zangwill LM, Bowd C, Vessani RM, Susanna R Jr, Weinreb RN. Evaluation of retinal nerve fiber layer, optic nerve head, and macular thickness measurements for glaucoma detection using optical coherence tomography. Am J Ophthalmol. 2005;139(1):44-55.

10. Garway-Heath DF, Holder GE, Fitzke FW, Hitchings RA. Relationship between electrophysiological, psychophysical, and anatomical measurements in glaucoma. Invest Ophthalmol Vis Sci. 2002;43(7):2213-20.

11. Kuo MT, Lai IC, Teng MC. Serial follow-up in traumatic optic neuropathy using scanning laser polarimetry and visual field testing. Chang Gung Med J. 2005; 28(8):581-6.

12. Miyahara T, Kurimoto Y, Kurokawa T, Kuroda T, Yoshimura N. Alterations in retinal nerve fiber layer thickness following indirect traumatic optic neuropathy detected by nerve fiber analyzer, GDx-N. Am J Ophthalmol. 2003;136(2):361-4.

13. Medeiros FA, Susanna R Jr. Retinal nerve fiber layer loss after traumatic optic neuropathy detected by scanning laser polarimetry. Arch Ophthalmol. 2001; 119(6):920-1.

14. Meier FM, Bernasconi P, Stürmer J, Caubergh MJ, Landau K. Axonal loss from acute optic neuropathy documented by scanning laser polarimetry. $\mathrm{Br} \mathrm{J}$ Ophthalmol. 2002;86(3):285-7. 